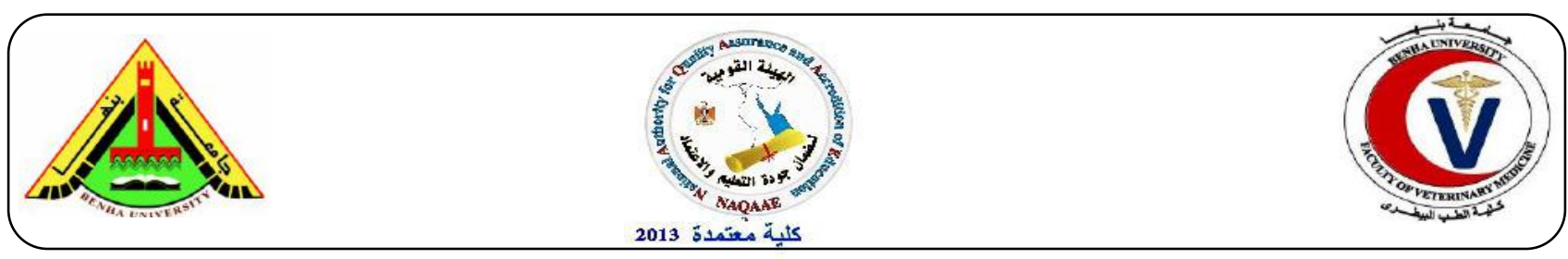

\title{
Experimental infection of goslings with Duck Hepatitis Virus type-1
}

\author{
Ahmed, B.A. ${ }^{\text {; }}$ El-Bagoury, G.F. ${ }^{2}$; El-Habbaa, A.S. ${ }^{2}$; Khodeir, M.H. ${ }^{3}$ \\ ${ }^{1}$ Military Veterinary Services, Egypt \\ ${ }^{2}$ Department of Virology, Faculty of Veterinary Medicine, Benha University \\ ${ }^{3}$ Veterinary Serum and Vaccine Research Institute, Abassia, Cairo
}

\begin{abstract}
A B S T R A C T
The present work investigated the susceptibility of goslings to infection with Duck Hepatitis Virus type-1 (DHV-1) and their possible role for hazard spread of infection to ducklings. It was noticed that experimentally infected one-week old goslings were susceptible to infection with DHV-1 showing clinical signs started by the $4^{\text {th }}$ day post infection detected in 4 out 10 goslings represented by dullness and weakness. Two goslings were recovered, and other 2 birds were died one-week post infection. In contact ducklings showed classical signs of DHV-1 infection represented by weakness and sudden death. DHV-1 was recovered from liver, spleen and kidneys of experimentally dead birds. Survived goslings exhibited detectable neutralizing antibody titers by the $1^{\text {st }}$ week post infection. Vaccination of goslings with the live attenuated DHV-1 vaccine resulted in good immune response of high antibody levels up to 10 weeks post vaccination. So, it could be said that goslings were susceptible to DHV-1 and may play a role in transmission of DHV-1 to duckling and it could be recommended to vaccinate gosling against DHV-1 infection
\end{abstract}

Keywords: Duck hepatitis virus type- 1 (DHV-1); Gosling; duckling.

(http://www.bvmi.bu.edu.eg)

(BVMJ-35(1): 134-144, 2018)

\section{INTRODUCTION}

Geese are among the fastest-growing avian species commonly raised for meat. Goose meat is fatter than other poultry meats, but it is well accepted by many local populations, including some in West Africa. In Egypt, geese are found widely as scavengers around the villages (Smith, 1990).

Duck viral hepatitis is an acute highly contagious disease of young ducklings characterized by high mortality and liver lesions with hemorrhagic foci. Virus of infectious hepatitis of ducks was first isolated by Levine and Fabricant in 1950 from outbreaks of disease in Long Island and characterized by a high mortality in young ducklings (Levine, et al, 1950). There are three distinct types of duck hepatitis virus (DHV; types 1-3) have been identified from diseased ducklings (Woolcock, 2003 and Monroe et al., 2005)

DHV-1 is renamed duck hepatitis A virus (DHAV) and is assigned to the novel genus Avihepatovirus within the family Picornaviridae (Knowles et al., 2012). DHAV is divided genetically into three different genotypes found in south Asia: the original 
genotype DHAV-1, a new genotype DHAV-2 isolated in Taiwan and new genotype DHAV3 isolated in South Korea and China (Fu et al, 2008).

DVH-1 had been described to occur in Egypt since late 1970s (Shalaby et al., 1978). It was diagnosed in 46 commercial duck farms (Pekin, Muscovy, Mallard and Green Winged) in Egypt with a history of high mortality in young ducklings from 3 to 15 day-old from 2012 to 2014 (Erfan, et al., 2015). The disease was diagnosed in Blencher duckling flocks with $70 \%$ recurrent mortality on each reared batch (Bayoumie and Abd AlSamie, 2015).

The most of presented studies revealed that geese could be experimentally infected by DHV-1 (OIE, 2009) or may be infected by new serotype of DHV-1 (Liu et al., 2011). However. the role of geese in transmission of DVH-1 has not yet been studied. So, the aim of the present work was directed to study the susceptibility of gosling to infection with DHV-1 and their possible role for hazard spread of infection to duckling in addition to study the benefit of their vaccination with the locally produced vaccine.

\section{Materials and methods}

\subsection{Viruses:}

2.1.1. Virulent Duck Hepatitis Virus-1 (DHV-1): A local isolate of duck hepatitis virus-1 was supplied by Veterinary Serum and Vaccine Research Institute (VSVRI) Abbasia, Cairo. It had a titer of $10^{8} \mathrm{EID}_{50} / \mathrm{ml}$ and used for experimental infection of gees.

\subsubsection{Cell culture adapted DHV-1:}

Vero cell culture adapted DHV-1 (El-Koffy, 1997) with a titer of $6 \log 10 \mathrm{TCID}_{50} / \mathrm{ml}$ was supplied kindly by VSVRI and used in serum neutralization test.

\subsection{Anti-DHV-1 hyper immune serum:}

It was supplied kindly by VSVRI and used in virus neutralization test to confirm DHV-1 recovery.

\subsection{Duck hepatitis vaccine:}

Live attenuated duck hepatitis vaccine was supplied by VSVRI and used for vaccination of experimental birds.

\subsection{Cell culture:}

African green monkey kidney (Vero) cell monolayer was supplied by VSVRI and used for estimation of $\mathrm{DH}$ antibodies in sera of vaccinated birds using serum neutralization test.

2.5.Specific Pathogen Free-Embryonted Chicken Eggs (SPF-ECE):

Fifty SPF-ECE, 8-10 days incubated at $38{ }^{\circ} \mathrm{C}$ and $65 \%$ relative humidity were supplied by VSVRI and used in trials for virus recovery from tissue samples of infected dead birds.

\subsection{Experimental birds:}

Thirty, 7 days old commercial goslings and ten, 7 days old ducklings of native breed were purchased from a local market and reared under strict hygienic measure in isolated and disinfected wire floored cages. All birds were screened before application of the experimental work using serum neutralization test (SNT) and found to be free from duck hepatitis antibodies.

\subsection{Experimental infection of goslings with} DHV-1:

The thirty goslings were divided into three groups and treated as follow:

Group (1): Ten goslings infected with virulent DHV-1 strain using a dose of $0.5 \mathrm{ml} /$ bird injected intramuscularly according to Woolcock (2008). These birds were kept under observation for daily detection of clinical signs and mortality for 14 days. Ducklings were kept in contact with experimentally infected goslings.

Group (2): Fifteen goslings were subcutaneously vaccinated with DHV-1 vaccine with $0.5 \mathrm{ml} /$ bird $\mathrm{I} / \mathrm{M}$. The goslings 
were weekly examined serologically up to 10 weeks post vaccination for antibody response. Five goslings of this group were challenged 3 weeks post vaccination against the virulent DHV-1 while the other ten goslings were kept to follow up the level of induced antibodies.

Group (3): Five goslings without vaccination and without infection were kept separately under hygienic measures as control.

\subsection{Sampling:}

\subsubsection{Samples for virus recovery:}

Specimens of liver, spleen, and kidneys, were collected from birds died after infection for virus recovery after application of the post mortem examination. These specimens were homogenized using tissue homogenizer and after three cycles of freezing and thawing, the homogenate was clarified by centrifugation at $3000 \mathrm{rpm}$ for 10 minutes (OIE, 2010). The supernatant fluid was treated with $100 \mathrm{IU} / \mathrm{ml}$ penicillin and $100 \mu \mathrm{g} / \mathrm{ml}$ streptomycin then kept at $-80^{\circ} \mathrm{C}$ for virus isolation.

\subsubsection{Serum samples:}

Blood samples without anticoagulant for serum collection were obtained from all bird groups one-week intervals post application of the experimental work.

\subsection{Virus recovery:}

\subsubsection{Egg inoculation:}

Egg inoculation technique was carried out according to Senne in ECE 8-10 days-old using $0.2 \mathrm{ml} / \mathrm{egg}$ of suspected DHV homogenate via allantoic cavity.

\subsubsection{Titration of $D H V-1$ in ECE:}

Each of serial ten-fold dilutions of the allantoic fluid obtained from the inoculated eggs from the 1st passage, and 2nd passage; was inoculated in five 8-10 days old ECE with $0.1 \mathrm{ml} / \mathrm{egg}$ up to a dilution of $10^{-8}$ via allantoic sac. EID $_{50}$ was calculated by Reed and Muench (1938).

2.10. Virus neutralization test (VNT):
It was carried out according to Woolcock, (1989) using hyper immune serum against DHV type I through inoculation into allantoic cavity of five ECE $(0.1 \mathrm{ml} / \mathrm{egg})$.

\subsection{Serum Neutralization Test (SNT):}

SNT was carried out on Vero cell culture using the micro titer technique to follow up the levels of $\mathrm{DH}$ antibodies in the sera of experimental birds according to Bass et al., (1982). and the antibody titer was calculated as the reciprocal of the final serum dilution which neutralized and inhibited the CPE of $1_{100 T_{C I D}}$ of DHV-1 according to Singh et al (1967).

\section{RESULTS}

\subsection{Clinical examination of infected birds:}

It was noticed that goslings showed mild clinical signs started at the $4^{\text {th }}$ day post infection with DVH-1. These signs were detected in 4 out of 10 goslings represented by dullness, depression and weakness, (Table1 and photo-1). Recovery occurred to 2 out of 4 affected goslings 1-week post infection and 2 birds were died (Photo-2).

In contact ducklings showed classical signs of DHV-1 (8 out of 10 duckling) represented by depression; weakness and sudden death occurred in opisthotonus position (photo-3). These observations are demonstrated in table (2). Deaths of affected (5) duckling were recorded by $2^{\text {nd }}$ day post infection. Photo (4). These findings are tabulated in table (2).

Goslings showed symptoms of infection in 4 out of 10 experimentally infected birds of which 2 were died, while ducklings showed symptoms of infection in 8 out of 10 experimentally infected birds of which 5 were died, (table 3 and 4).

\subsection{Examination of post-mortem lesions in dead birds:}

PM lesions of died gosling and ducklings showed congestion of internal organs and 
mottled liver as shown in photos $(5,6,7$ and 8).

\subsection{Recovery of the DHV from dead birds:}

It was found that DHV could be recovered from the liver and kidneys of died birds through 2 serial passages in SPF embryonated chicken eggs (Table-4)

Although it had a low titer $(5.5 \log 10$ EID 50 $/ \mathrm{ml}$ and $6.5 \log 10$ EID $50 / \mathrm{ml})$ by the $1^{\text {st }}$ passage then increased to reach $(6.5 \log 10$ EID $50 / \mathrm{ml}$ and7.5 $\log 10$ EID $50 / \mathrm{ml}$ ) by the $2^{\text {nd }}$ passage from dead goslings and ducklings respectively (Table-5)

\subsection{Detection of serum neutralizing DHV-1} antibodies in survived goslings and ducklings:
Survived goslings and ducklings showed detectable SNT antibody titers from the first week and up to 3 weeks post infection. Survived goslings developed lower mean neutralizing antibody titers against DHV-1 than that was developed in survived duckling (Table-6).

\subsection{Evaluation of humoral immune response of goslings vaccinated with live DHV-1 vaccine:}

DHV-1 serum neutralizing antibodies were detectable in goslings by the $1^{\text {st }}$ week post vaccination, recording their peaks by the $6^{\text {th }}$ week post vaccination then remained constant up to 10 weeks post vaccination as shown in tables (7 and 8).

Table (1): Clinical response of goslings to experimental infection with DHV-1

\begin{tabular}{cc|cccccccccccc}
\hline \multicolumn{10}{c}{ Observed clinical signs on DPI* } \\
\hline 1 & 2 & 3 & 4 & 5 & 6 & 7 & 8 & 9 & 10 & 11 & 12 & 13 & 14 \\
\hline \multicolumn{2}{l|}{ No symptom } & & 8 & \multicolumn{1}{c}{ Depression \&Weakness } \\
\hline $0 / 10$ & $0 / 10$ & $0 / 10$ & ${ }^{* * *} 1 / 10$ & $2 / 10$ & $3 / 10$ & $4 / 10$ & $4 / 10$ & $4 / 10$ & $4 / 10$ & $4 / 10$ & $4 / 10$ & $4 / 10$ & $4 / 10$ \\
\hline
\end{tabular}

*DPI= days post infection. ** Number of goslings showing signs of duck viral hepatitis type 1

Table (2): Clinical response of ducklings in contact experimentally infected gosling with DHV-1

\begin{tabular}{|c|c|c|c|c|c|c|c|c|c|c|c|c|}
\hline \multicolumn{13}{|c|}{ Observed clinical signs on DPI* } \\
\hline 2 & 3 & 4 & 5 & 6 & 7 & 8 & 9 & 10 & 11 & 12 & 13 & 14 \\
\hline No symptom & \multicolumn{12}{|c|}{ weakness and depression } \\
\hline $0 / 10 \quad 0 / 10$ & $* * 1 / 10$ & $4 / 10$ & $8 / 10$ & $8 / 10$ & $8 / 10$ & $8 / 10$ & $8 / 10$ & 810 & $8 / 10$ & $8 / 10$ & $8 / 10$ & $8 / 10$ \\
\hline
\end{tabular}

${ }^{*} \mathrm{DPI}=$ days post infection. $* *$ Number of ducklings showing signs of duck viral hepatitis type 1

Table (3): Rate of infection in goslings after experimental inoculation with DHV-1

\begin{tabular}{lccc}
\hline Birds & $\begin{array}{c}\text { Number } \\
\text { of birds }\end{array}$ & $\begin{array}{c}\text { Diseased } \\
\text { birds }\end{array}$ & $\begin{array}{c}\text { Dead } \\
\text { birds }\end{array}$ \\
\hline Goslings & 10 & 4 & 2 \\
Contact ducklings & 10 & 8 & 5 \\
\hline
\end{tabular}


Table (4): DHV recovery from dead infected goslings and duckling

\begin{tabular}{|c|c|c|c|c|c|c|c|c|c|c|c|}
\hline \multirow[t]{2}{*}{ Type of sample } & \multirow[t]{2}{*}{$\begin{array}{l}\text { No. of } \\
\text { sample }\end{array}$} & \multirow[t]{2}{*}{ organ } & \multirow[t]{2}{*}{$\begin{array}{c}\text { No. of } \\
\text { positive } \\
\text { samples }\end{array}$} & \multicolumn{6}{|c|}{$\begin{array}{l}\text { Embryonic deaths / } \\
\text { days post inoculation }\end{array}$} & \multicolumn{2}{|c|}{$\begin{array}{c}\text { Total } \\
\text { embryonic } \\
\text { deaths }\end{array}$} \\
\hline & & & & 1 & 2 & 3 & 4 & 5 & 6 & No. & $\%$ \\
\hline \multirow{3}{*}{ Infected goslings } & \multirow{3}{*}{4} & liver & 3 & 0 & 0 & 2 & 1 & 0 & 0 & $3 / 4$ & 75 \\
\hline & & kidney & 2 & 0 & 0 & 0 & 2 & 0 & 0 & $2 / 4$ & 50 \\
\hline & & spleen & 1 & 0 & 0 & 0 & 1 & 0 & 0 & $1 / 4$ & 25 \\
\hline \multirow{3}{*}{$\begin{array}{l}\text { Ducklings in } \\
\text { contact to } \\
\text { infected goslings }\end{array}$} & & liver & 4 & 0 & 0 & 1 & 2 & 1 & 0 & $4 / 4$ & 100 \\
\hline & & kidney & 2 & 0 & 0 & 1 & 1 & 0 & 0 & $2 / 4$ & 50 \\
\hline & & spleen & 1 & 0 & 0 & 1 & 0 & 0 & 0 & $1 / 4$ & 25 \\
\hline
\end{tabular}

Table (5): Titration of DHV recovered from liver sample of infected goslings and ducklings.

\begin{tabular}{ccccc}
\hline \multirow{2}{*}{ Sample } & Culture & \multicolumn{3}{c}{ Titer of recovered DHV-1 $(\log 10$ EID50/ml) } \\
& System ECE & Liver sample & First passage & Second passage \\
\hline Dead gosling & 15 & 4.5 & 5.5 & 6.5 \\
Dead ducking & 15 & 5.5 & 6.5 & 7.5 \\
\hline
\end{tabular}

Table (6): Mean antibody titers against DHV-1 in sera from infected goslings and contact ducklings.

\begin{tabular}{|c|c|c|c|c|}
\hline \multirow{2}{*}{$\begin{array}{c}\text { Applied } \\
\text { Test }\end{array}$} & \multirow[t]{2}{*}{ Infected Bird } & \multicolumn{3}{|c|}{$\begin{array}{c}\text { antibody titers against } \\
\text { DHV-1/ WPI }\end{array}$} \\
\hline & & 1 & 2 & 3 \\
\hline \multirow{2}{*}{$\mathrm{SNT}^{* *}$} & Goslings & 1 & 4 & 16 \\
\hline & Contact Ducklings & 8 & 16 & 32 \\
\hline
\end{tabular}

Table (7): Mean serum neutralizing antibody titers against DHV-1 in gosling groups vaccinated with live attenuated duck hepatitis vaccine.

\begin{tabular}{ccc}
\hline $\begin{array}{c}\text { Weeks post } \\
\text { Vaccination }\end{array}$ & $\begin{array}{c}\text { Vaccinated } \\
\text { goslings }\end{array}$ & $\begin{array}{c}\text { Non-vaccinated } \\
\text { Control gosling }\end{array}$ \\
\hline 0 & 0 & 0 \\
1 & 4 & 0 \\
2 & 8 & 0 \\
3 & 32 & 0 \\
4 & 32 & 0 \\
6 & 64 & 0 \\
8 & 64 & 0 \\
10 & 64 & 0 \\
\hline
\end{tabular}

$* \overline{\mathrm{DH}}$ serum neutralizing antibody titer $=$ the reciprocal of the final serum dilution which neutralized and inhibited the CPE of 100 TCID $_{50}$ of DHV. 
Table (8): Efficacy of gosling vaccination against DH virus infection

\begin{tabular}{cccccc}
\hline $\begin{array}{c}\text { Goslings } \\
\text { groups }\end{array}$ & $\begin{array}{c}\text { No. of goslings } \\
\text { vaccinated }\end{array}$ & $\begin{array}{c}\text { No. of goslings No. of gosling } \\
\text { challenged }\end{array}$ & $\begin{array}{c}\text { Protection } \\
\text { affected }\end{array}$ & $\begin{array}{c}\text { Virus recovery of } \\
\text { percentage } \\
\text { affected goslings }\end{array}$ \\
\hline $\begin{array}{c}\text { Vaccinated } \\
\text { gosling }\end{array}$ & 10 & 10 & 0 & 100 & - \\
$\begin{array}{c}\text { Unvaccinated } \\
\text { control goslings }\end{array}$ & 5 & 3 & 2 & 60 & + \\
\hline
\end{tabular}

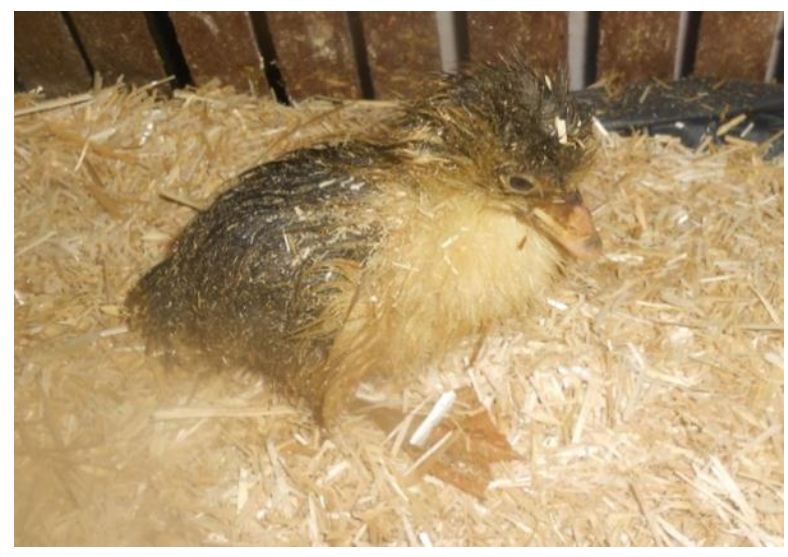

Fig.1. Experimental infected gosling with DH virus showing depression and inability to move.

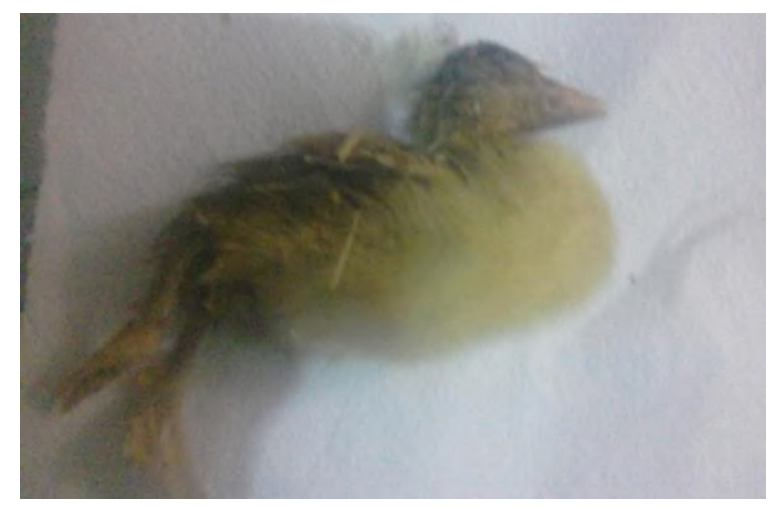

Fig.2. dead infected gosling with DHV-1.

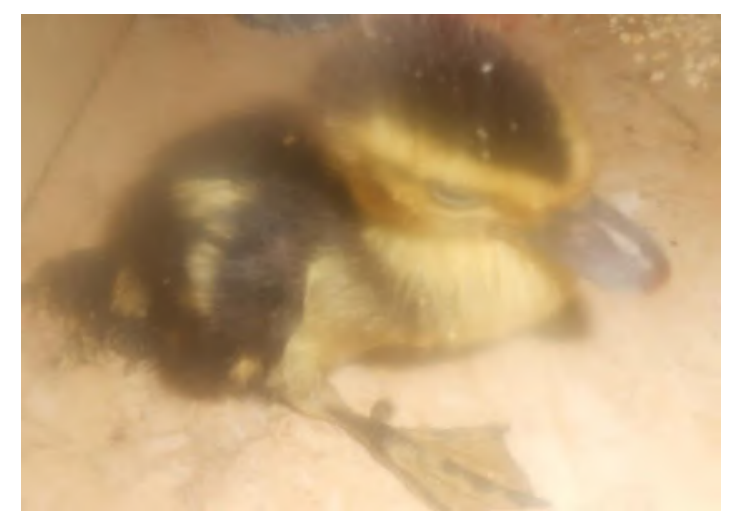


Fig.3. Contact duckling to infected goslings with depression and inability to move.

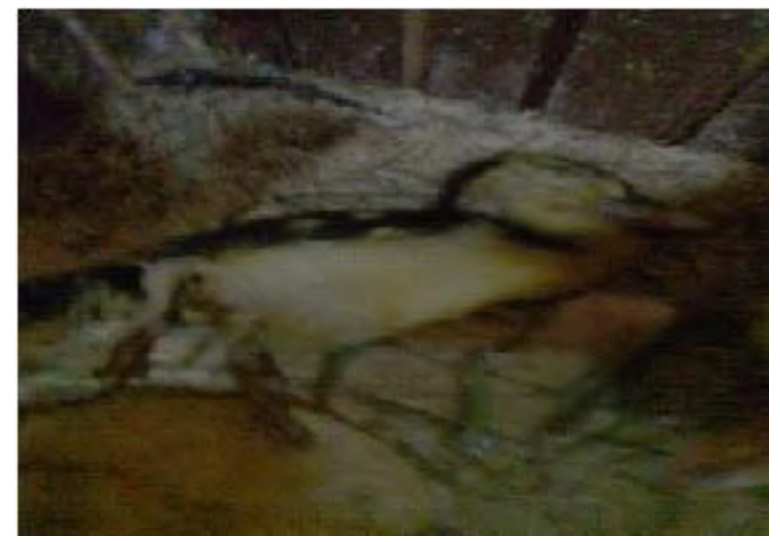

Fig.4. Dead infected duckling with DHV-1 showing opithotonus.

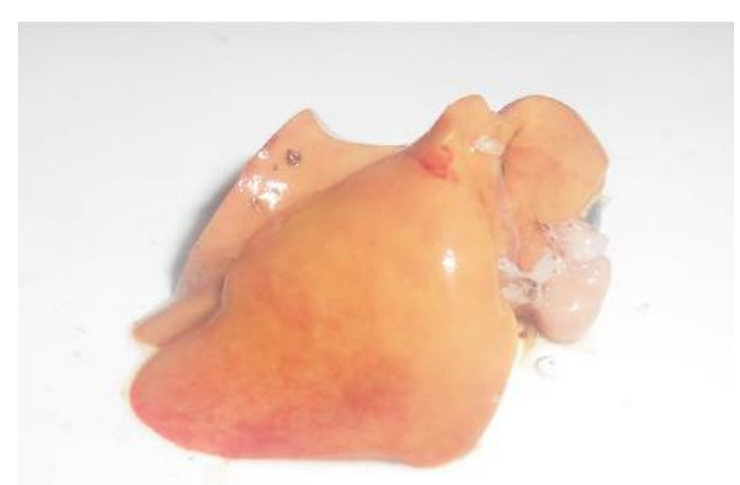

Fig.5. liver of dead gosling with DHV-1 showing hemorrhage.

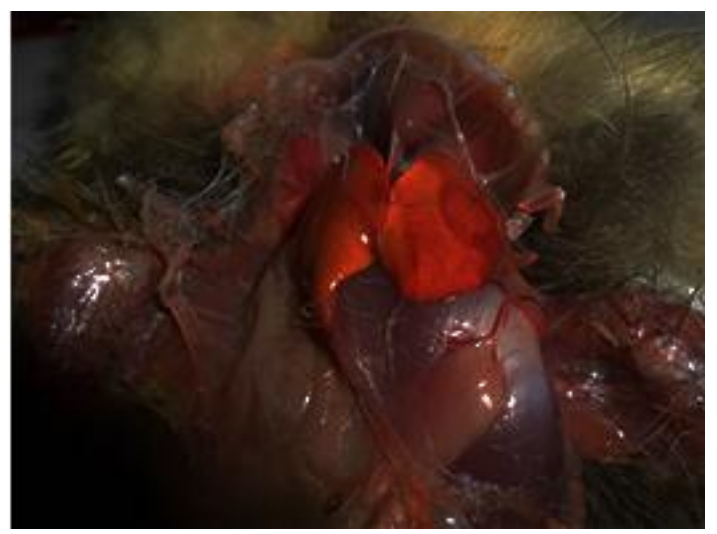

Fig.6. liver of dead gosling with DH virus showing hemorrhage.

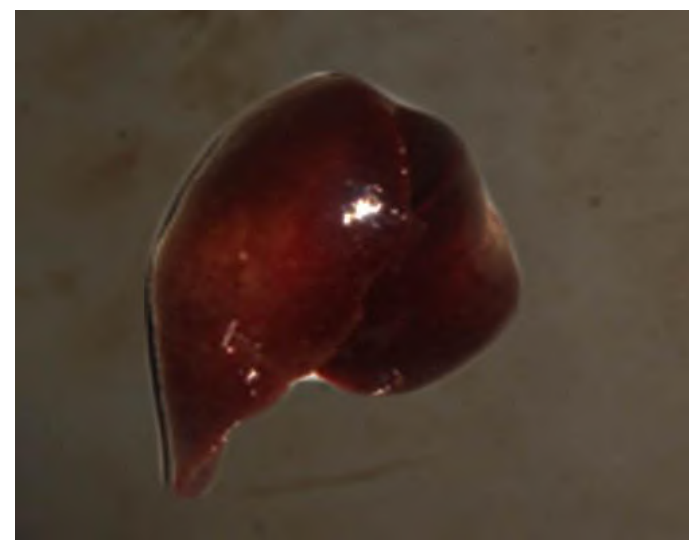


Fig.7. liver of dead duckling with DHV-1 showing hemorrhage.

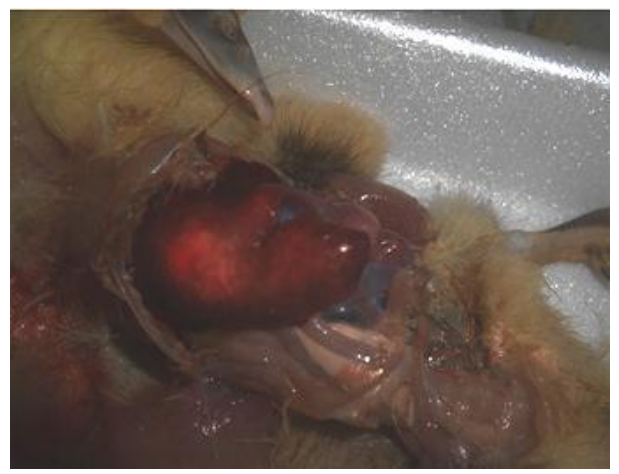

Fig.8. dead duckling with DHV-1 showing hemorrhage.

\section{DISCUSSION}

The study of susceptibility of gees to DHV-1 infection and their possible role in transmission of DHV-1 to ducks and detect if it could be infected from infected duck by DHV-1 designed the present work interest.

The most of presented studies reveal that gees could be experimentally infected by DHV-1 (OIE 2009) or it may be infected by new serotype of DHV-1 (Liu et al., 2011).

The obtained results revealed that goslings were susceptible to infection with DHV-1 with low morbidity rate (4 out of 10 goslings) started at the $4^{\text {th }}$ day post infection and represented by dullness, weakness and inability to move followed by sudden death. Clear typical clinical signs appear on contact ducklings and mortality rate of $50 \%$ (5 out of 10 ducklings were died). The clinical signs include weakness, dullness, ataxia and loss of balance and death in opisthotonus position. These results came in agreement with clinical signs showed by Asplin and Mclauchlan (1954); Shalaby et al., (1972); Woolcock (1989); Jordan (1990) and Jordan and Pattison (1996) and Woolcock (2003) who reviewed that DHV type I affects ducklings less than 6 weeks of age with incubation period less than 24 hours following natural and experimental infection. They describe the clinical signs including weakness, dullness, ataxia and loss of balance. Affected ducklings lied on their side showing spasmodic movement and kicking by their legs, then die in an opisthotonus position.

Morbidity and mortality rates among experimentally infected birds were $40 \%$ and $20 \%$ respectively in goslings and $80 \%$ and $50 \%$ among contact ducklings that came in agreement with Woolcock (2008) who showed that morbidity is $100 \%$ and mortality is variable in young ducklings infected with DHV type 1 . In some breeds less than one week old, mortality may reach $95 \%$. In ducklings 1-3 week of age, mortality may be $50 \%$ or less. In ducklings 4-5 week of age, morbidity and mortality are low or negligible.

DHV-1 was recovered from the liver, spleen and kidneys of dead goslings through the inoculation into allantoic cavity of embryonated chicken eggs (ECE). The embryos were showed stunting; hemorrhage over the whole body and edema, 3 days post infection coming in agreement with Woolcock (1996 and1998) who used inoculation of $0.1 \mathrm{ml}$ serial dilution of tissue homogenate of DHV type I infected ducklings into the allantoic cavity (AC) of embryonated duck eggs of 10-14 days old from a DHV type I-free flock chicken eggs of 9 days old at $37 \mathrm{oC}$, infected duck embryos die within 2472hours; chicken embryos are more variable in their response and usually take5-8 days to 
die, the allantoic fluid is opalescent or a pale greenish-yellow, green yolk and gross pathological changes in the embryos include stunting and subcutaneous hemorrhage over the whole body, with edema, particularly of the abdominal and hind limb regions, embryo livers may be swollen, red and yellowish in color with necrotic foci, the liver lesions are more apparent in embryos that take longer time to die. The embryonic deaths of duck embryos occurred at2nd day after inoculation but for chicken embryos at 3rd day after inoculation, embryos of both showed stunting, edema over the whole body especially around the head, skin hemorrhage and congestion, in embryos that take longer time to die (5-6 days after inoculation) showed greenish discoloration and focal necrosis of liver and green color egg yolk

Titration of recovered DHV in ECE from liver sample of infected goslings and ducklings showed a low titer by the 1st passage in ECE (4.5log10 EID ${ }_{50} / \mathrm{ml}$ ) and (5.5 $\log 10$ EID ${ }_{50} / \mathrm{ml}$ ) from dead goslings and ducklings respectively then increased to reach (6.5 log 10EID ${ }_{50} / \mathrm{ml}$ and $7.5 \log 10$ EID 50 $/ \mathrm{ml}$ ), respectively by the $2 \mathrm{rd}$ passage. This result agreed with those obtained by Metwally (1998) and Elkoffy (1997) who recorded ECE isolation and titration of DHV in liver suspension that were $10^{7}$ EID50 $/ \mathrm{ml}$, and $10^{8.31}$ EID50 $/ \mathrm{ml}$ respectively.

Serum neutralization test revealed that such experimentally infected goslings had neutralizing antibody titer of 2 and 16 on the $1^{\text {st }}$ and $3^{\text {rd }}$ week post infection respectively. Parallel to these findings, in contact survived ducklings exhibited serum neutralizing antibody titers 8 and 32 on the $1^{\text {st }}$ and $3^{\text {rd }}$ week post exposure, respectively. DHV-1 serum neutralizing antibodies were detectable in gosling by the $1^{\text {st }}$ week post vaccination (2) recording their peaks (64) by the $6^{\text {th }}$ week post vaccination then remained constant up to 10 weeks post vaccination.

Jordan and Patisson (1996) mentioned that a live attenuated virus vaccine propagated in chicken embryos has been used successfully by $\mathrm{S} / \mathrm{C}$ inoculation before the ducks go out on to the field.

\section{Conclusion}

It could be concluded that goslings could be infected with DHV-1 and could transmit the infection to duckling. Goslings had good response to DHV-1 vaccine. It could be suggested that on the long term the virus may circulate in goslings and increase its virulence causing outbreaks affecting both gosling and duckling populations.

\section{REFERENCES}

Asplin, F.D.; Mclauchlan, J.D. 1954. Duck virus hepatitis. Record 66:456-458.

Bass, E.P.; Gill, M.A.; Beckenhaur, W.H. 1982. Development of a modified live canine origin parvo virus vaccine. J. Am. Vet. Med. Ass., 181, (9): 909- 913

Bayoumie, H.A.A.; Abd Al-Samie, L.K. 2015. Molecular characterization of a Duck Virus Hepatitis isolates isolated from Sharkia governorate. Assiut Vet. Med. J. Vol. 61 No. 147 pp. 56-65.

El-Koffy, M.A. 1997. Studies on the preparation and evaluation of a vaccine prepared from a local strain of duck virus hepatitis. Thesis Ph.D. VSc. Fac. of Vet. Med Department of Poultry and rabbit diseases.

Erfan, A.M.; Selim, A.A.; Moursi, M.K.; Nasef, S.A.; Abdelwhab, E.M. 2015. Epidemiology and molecular characterization of duck hepatitis A virus from different duck breeds in Egypt. Vet. Microbiol.; 177(3-4):34752. 
Fu, Y., Pan, M.; Wang, X.; Xu, Y.; Yang, H.; Zhang, D. 2008. Molecular detection and typing ofduck hepatitis A virus directly from clinical specimens. Vet. Microbiol, 131: 247-257.

Jordan, F.T.W. 1990. Poultry dis. ELBS. 3rd ed., printed in Great Britainby the Univ. Press. Cambridge.

Jordan, F.T.W.; Pattison, M. 1996. Poultry dis.4th ed., W. B. SaundersCo. Ltd. London, Philadelphia Toronto Sydney Tokyo.

Knowles, N.J., T. Hovi, T. Hyypiä, A.M.Q. King,A.M. Lindberg, M.A. Pallansch, A.; Palmenberg, C.; Simmonds, P.; Skern, T.; Stanway, G.; Yamashita, T.; Zell, R. 2012. Picornaviridae. In: King, A.M.Q., M.J. Adams, E.B. Carstens, E.J. Lefkowitz, eds. Virus Taxonomy: Classification and Nomenclature of Viruses: Ninth Report of the International Committee on Taxonomy of Viruses. Elsevier, San Diego, pp: 855-880.

Levine, P.P., Fabricant, J.; Hitherto, A. 1950. Undescribed virus disease in ducks in North A-merica. Cornell Vet., 40: 7186 Liu, M.; Meng, F.; Li, X.; Zhang, Z.; Liu, S.; Zhang, Y. 2011. Goose haemorrhagic hepatitis caused by a new subtype duck hepatitis type 1 virus. Veterinary Microbiology 152: 280-28.

Metwally, A.Y. 1998. Some Studies on Viral Diseases of Ducks with Special Reference to Duck Virus Hepatitis and Duck Virus Enteritis. A thesis of Ph.D. VSc., Poultry and Rabbit Dis., Faculty of Veterinary Medicine Zagazig Univ.

Monroe, S.S.; Carter, M.J.; Herrmann, J.; Mitchel, D.K.; Sanchez-Fauquier, A., 2005. Virus taxonomy. In: Fauquet, C.M., Mayo, M.A., Maniloff, J., Dessel berger, U., Ball, L.A. (Eds.), Eighth Report of the International Committee on Taxonomy of Viruses Family
Astroviridae. Elsevier/Academic Press, London, pp. 859-864.

OIE. 2009. World Animal Health Information Database - Version: 1.4. World Animal Health Information Database Paris, France: World Organisation for Animal Health available online at http://www.cabi.org/isc/datasheet/8418 4.

OIE, 2010. Duck Virus Hepatitis. OIE Terrestrial Manual 2010. (Chapter 2.3.8), http://www.oie.int/fileadmin/Home/eng /Health_standers/tahm/2.03.08_DHV.p df.

Reed, L.J.; Muench, H.H. 1938. A simple method of estimating $50 \%$ end point. Am. J. Hyg. 27:493-497

Senne, D.A. 1989. Virus propagation in embryonating eggs. A laboratory manual for the isolation and identification of avian pathogens, The Am. Ass. Of Avian pathologist, 3rd ed. Pp. 176-181

Singh, K.V.; Osman, O.A.; Thanaa, I. Baz; Ivon El-Cicy 1967. Colostral transfer rinder pest neutralizing antibodies to offspring of vaccinated dams. Canadian Journal Comparative Medicine Veterinary Science; 31:295298.

Shalaby, M.A.; Ayoub, M.N.K.; Reda, I.M. 1978. A studies on a new isolate of duck hepatitis virus strains. Vet. Med. J., Cairo Univ., 26: 215 - 221.

Shalaby, M.A. 1972. Some studies on viruses affecting ducks with characterization of the isolates. Thesis M. Sc., Poultry dis., Cairo Univ.

Smith, A.J., 1990. Poultry In The tropical agriculturalist. (CTA); the Netherlands, MacMillan Press Ltd

Woolcock, P.R. 1989. Duck virus hepatitis. In Purchase H.G., et al (eds.):A 
Laboratory Manual for the Isolation and Identification of Avian Pathogens 3rd ed. Dubuque, Kendall / Hunt Publishing Co., pp.;152-155.

Woolcock, P.R. 1996. Duck Virus Hepatitis. In Manual of Standards for diagnostic Tests and Vaccines, 3rd ed. Office International des Epizooties, Paris France 561-567

Woolcock, P.R. 1998. Duck Hepatitis. In D.E. Swayne, et al. A Laboratory Manual for the isolation and identification of Avian Pathogens, 4th edition. American Association of Avian Pathologists P.A. 200-204.

Woolcock, P.R. 2003. Duck hepatitis. In: Saif Y.M., H.J. Barnes, J.R. Glisson, A.M. Fadly, L.R.Mcdougald and D.E. Swayne, eds. Diseases ofPoultry. Eleventh ed. Iowa State Press, Ames, IA.,pp: 343-354

Woolcock, P.R. 2008. Duck hepatitis. In: Saif Y.M., H.J. Barnes, J.R. Glisson, A.M. Fadly, L.R. Mcdougald and D.E. Swayne, eds. Diseases of Poultry. Twelfth ed. Iowa State Press, Ames, IA.,p: 376. 